\title{
TOWARDS A LABOR RIGHT WITH A HUMAN FACE*
}

\author{
Alberto CHARTZMAN BIRENBAUM ${ }^{*}$
}

\begin{abstract}
There can be no development without human rights, just as there are no human rights without development. Furthermore, peace and security are essential for development and respect for human rights. A phrase that sums up and frames very well what the 2030 Agenda means: a roadmap to the world that we want and that we are already building. To help stabilize an economic model in democracy that puts the human person at the center and promotes social inclusion must create conditions that allow decent work. The challenges posed by globalization need human faces for world, regional and national development, through the reaffirmation of essential and universal values. In this context, work constitutes an ethical value, a decisive and determining factor for production. From this premise arises the right to work as a source of personal dignity, family stability and consolidation of social cohesion. It synthesizes the aspirations of people during their working life. It means the opportunity to access a productive job that generates a fair income, security in the workplace and social protection for families; better prospects for personal development and social integration, and equal opportunities and treatment for women and men. Decent Work, that ethical-evaluative assessment designed by the ILO in the 90s at the 89th annual meeting, today in 2021 is still a search paradigm. We are convinced that the worker must be the central axis of the system, subject to preferential guardianship. For this we need all workers to respect their fundamental labor principles and rights, enjoy a fair income, a work environment without gender discrimination or of any other type, where social protection is provided.
\end{abstract}

Keywords: Future work; Decent; Human face

DOI: $10.53373 /$ REDS.2021.52.3.022

Work is a means of sustaining life and meeting basic needs. But it is also the activity by which people affirm their own identity, both to themselves and to those around them.

Work is crucial for the exercise of personal choices, for the well-being of the family and for the stability of society.

The essence of what people want remains constant, across cultures and levels of development. Everyone seeks an equal opportunity to prosper in life through their own efforts. But they also want a second chance when they take risks and fail. People are not so afraid of change, or even failure, as they are of exclusion. ${ }^{1}$

\footnotetext{
* Paper presented at the International Conference "The future of labor law after coronavirus" organized on-line by the Association for the Study of Professional Labor Relations on May 13 and 14, 2021.

** Doctor in labor law, master in labor law and international labor relations, graduate in human relations, lawyer, National University Three of February.

1 Juan Somavía. Reducir el déficit de trabajo decente un desafío global. Ginebra, OIT. En OTG www.observatoriodeltrabajo.org. OIT (2001).
} 
The first of the principles of the Declaration of Philadelphia, on the goals and objectives of the International Labor Organization, of May 10, 1944, indicates that work is not a commodity. Economic studies show that putting downward pressure on labor leads to economic inefficiency. People cannot be subject to market fluctuations. The salary received for the performance of a job is the only way for most individuals to obtain sufficient income to sustain their lives and satisfy their basic needs and those of their family. Employment is therefore a fundamental means of human development.

Even conventional economic theory has had to recognize the positive effects that wages or social coverage have on productivity. Hence the questions that are already being asked -although it is still incipient of the limits that the so-called labor flexibility introduces in the functioning of the economies, noting how the process of growing precariousness entails macroeconomic and productive inefficiency. ${ }^{2}$

The Core Labor Standards emanate from the ILO. The International Labor Conference at its 86th session in 1998 adopted a Declaration on fundamental principles and rights at work, to reinforce respect for the rights of workers and to help reduce the negative effects of globalization.

The substantial importance of this Declaration resides in the fact that these fundamental conventions do not need, like the others, to be ratified by the member states in order to become binding (to constitute a legal obligation) but that every State, by virtue of belonging to the ILO, must comply with them, regardless of whether or not the Member State has ratified these conventions. The ILO develops international labor regulations through conventions and recommendations adopted by the International Conference of the ILO. However, despite its specialized competence in the regulation of labor rights, the ILO controls and supervises, but has no sanctioning power. In the case of freedom of association (an agreement ratified by 145 countries), and the right to organize and to collective bargaining (ratified by 154 countries), its non-compliance by 2 out of 5 countries in the world represents a double violation, given that they are ratified conventions that are also fundamental labor standards

The ILO, in its 2006 Global Employment Trends report, notes that the number of unemployed people in the world registered a new increase in 2005 despite the good data on world economic growth. This report offers us the following data: While world GDP grew by $4.3 \%$, the consequences on the labor market were not uniform. The number of people in employment increased but at the same time the total number of unemployed people at the end of the year stood at 191.8 million people, an increase of 2.2 million people since 2004 and 34.4 since 1995, which which represents a world unemployment rate of $6.3 \%$ Geographically, the region with the highest unemployment rate is the Middle East and North Africa, while the one in which the number of unemployed people has increased the most is Latin America

\footnotetext{
${ }^{2}$ Amat Sánchez Trabajo y Desarrollo. Globalización de la economía e internacionalismo obrero. País Valencia, Fundació Pau i Solidaritat. Pau i Solidaritat (1999).
} 
and the Caribbean. Women and young people are the most affected by unemployment. While women continue to bear the highest unemployment rates, nearly half of the world's unemployed population are young, while they only represent $25 \%$ of the working-age population.

In impoverished countries the problem lies not so much in the existence of unemployment, as in the working conditions of the people who have found employment, in relation to their salary levels, the protection or lack of protection of their social security systems, or the absence of trade union rights.

There is a "representation deficit" in the world of work, because, often and for various reasons, workers are unable to organize to make their voices heard. Agricultural, domestic, public sector and migrant workers are in they often face specific obstacles to freedom of association. Social dialogue is also impeded in the Industrial Free Zones (EPZs), in which some 27 million workers worldwide work. Everywhere, workers and employers in the informal economy are excluded or underrepresented in tripartite dialogue. Even when organized, the lack of institutional mechanisms can still impede dialogue.

There is currently a moderate growth of $9 \%$ in the number of migrant workers in the world, from 150 million in 2013 to 164 million in 2018. Women represent $47.5 \%$ of this flow, a continuously increasing proportion, attesting to the growing feminization of migratory flows. Although there are international standards that regulate equal treatment for migrants in terms of employment, salary, social security and trade union rights, they are the same legal instruments that have the least amount of ratifications. Only 45 countries have ratified the first of the ILO conventions that concern them (Convention No. 97), adopted in 1949 and only 19 countries signed Convention No. 143, opened for ratification in 1975. Likewise, in 1990 the The United Nations General Assembly adopted the International Convention for the Protection of the Rights of All Migrant Workers, which has only been ratified by 34 member states, mostly developing countries, and there are none of the main recipient countries among the signatories. of labor from North America or Europe. Thousands of workers fleeing poverty and death find themselves in the countries of the North with a reality that is not what they expected: difficulties to integrate into the regular labor market, jobs close to slavery, lack of rights, strenuous working hours... and furthermore, criminalized, and excluded. They have become a true "reserve army" that capitalism takes advantage of to make precarious and eliminate basic labor rights. In addition, for the countries of origin they represent a real "brain drain" as they lose their most qualified people.

In response to this, the data from the 2018 ILO annual report paint a calmer picture in which it is noted that migrant workers constitute $18.5 \%$ of the workforce in high-income countries.

Construction, domestic service or sanitation, continue to be common destinations for these people, added the expert. At least $23 \%$ of migrant workers remain in North America, $23.9 \%$ in Western Europe and 13.9\% in Arab countries, the region where there is a higher percentage of the workforce, according to the report. 


\section{Revue europénnee du droit social}

The number of migrants in the world reached 272 million in 2019, which is equivalent to 51 million more than in 2010, the majority staying in Europe (82 million) and North America (59 million), according to a published UN report this Tuesday.

In addition, she added that facilitating orderly and safe migration contributes to achieving the sustainable development goals set by the UN.

A general discussion on the social and solidarity economy for a people-centered future of work will be held during the 110th session of the International Labor Conference in 2022

The Governing Body of the International Labor Office (ILO), at its 341st meeting on March 30, 2021, decided to include a related item on the agenda of the 110th session (2022) of the International Labor Conference (ILC) with "The social and solidarity economy for a people-centered future of work", for general discussion.

This is a historic decision taken by the Governing Body of the ILO. In fact, it will be the first time that a general discussion on the social and solidarity economy (SSE) has been held at the ILC, which is an annual meeting of the delegates of the governments, workers and employers of the member states. of the ILO that takes place in June.

This decision indicates the increasing attention paid by governments and social partners to alternative economic models, which place people, rather than profit, at the center of their operations. It also provides an opportunity to shed light on the growing diversity of business models that are based on the values of cooperation, mutualism and solidarity, and that combine social, economic and environmental objectives. A central pillar of the social and solidarity economy is a people-centered and planet-sensitive approach to the economy. Therefore, a general discussion on SSE at the 2022 ILC is relevant to ILO constituents as they face the challenges of the post-pandemic era, with the $\mathrm{f}$ in to rebuild better.

At the ILO, this discussion is rooted in a number of relevant ILO Recommendations, notably the Promotion of Cooperatives Recommendation, 2002 (No. 193), the Employment Relationship Recommendation, 2006 (No. 198), and the Transition from the Informal to the Formal Economy Recommendation, 2015 (No. 204).

In recent years, a number of recent international labor standards, including the ILO Centennial Declaration for the Future of Work, have reflected on the importance of cooperatives and the SSE in general in addressing the challenges posed by the future of work.

At the same time, this general discussion provides a unique opportunity, among other things, to:

- provide a universal definition of the "social and solidarity economy", including its associated principles and values;

- assess the contribution of the SSE to the management and promotion of general support for people through the transitions they face throughout their working lives, and provide policy guidance to Member States wishing to establish an environment conducive to the national development of the SSE; 
- provide guidance to the Office on how to get involved in promoting the SSE worldwide, in particular through development cooperation, and

- Encourage the Office to create and maintain a wide range of partnerships with institutions, organizations and agencies that represent the SSE, or are involved in promoting the SSE.

The Office, guided by the work of its Cooperatives Unit and the Business Department, will prepare a document to guide this general discussion.

In December 2020, the Committee of Experts on the Application of Conventions and Recommendations recalled that the concrete commitments made by ILO member states to protect the dignity and freedom of people at work remain fully valid during the current pandemic and they strengthen the resilience of societies for better reconstruction. The CEACR, which has been monitoring the application of international labor standards since 1927, made the following particular observations:

The COVID-19 pandemic has been the greatest health crisis the world has witnessed in the ILO's centenary of existence and has left a massive social and economic crisis in its wake. Millions of people around the world have been exposed to the virus and, today, almost 1.6 million people have died. To address the health crisis, many governments have adopted containment measures, including lockdowns and similar restrictions, to prevent the spread of the virus. These measures have had a devastating impact on the labor market. While demand has increased in some sectors, such as healthcare and food retail, in other sectors it has virtually collapsed, such as tourism, aviation and transportation. Millions of businesses have closed and millions of jobs and livelihoods have been lost. Although the crisis has affected companies of all sectors and all sizes, micro, small and medium-sized companies, lacking sufficient human and financial resources to weather a crisis of these proportions, have been severely affected and many have simply suffered. what to close $\mathrm{e}^{3}$

Steps taken to contain the spread of the pandemic through quarantines, travel restrictions and lockdowns have led to a global recession and unprecedented levels of unemployment. According to World Bank ${ }^{4}$ estimates, given the impact of the pandemic, the number of people living in extreme poverty may increase by 150 million between now and 2021, representing the first increase in global poverty since 1998. At scale worldwide, the phenomenon of extreme hunger could double in 2020, affecting more than 260 million people and the increase in extreme poverty is likely to accentuate differences, magnify social and economic inequalities and generate new migratory flows, an increase in stigma and discrimination, and a growing digital divide. The crisis has exposed weaknesses in existing legal and political frameworks, which has exacerbated inequality and poverty and has paralyzed, or even reversed,

\footnotetext{
${ }^{3}$ Adenda de 2021 al Estudio General de 2020, Promover el empleo y el trabajo decente en un panorama cambiante

${ }^{4}$ Comunicado de prensa del Banco Mundial del 7 de octubre de 2020: Debido a la pandemia de COVID19, el número de personas que viven en la pobreza extrema habrá aumentado en 150 millones para 2021.
} 
progress towards sustainable development and the achievement of the SDG8 target of the full, productive and freely chosen employment, and decent work for all.

Social dialogue is of crucial importance in all aspects of the development, implementation, monitoring and review of policies in response to the COVID-19 crisis with a view to ensuring that they are based on respect for rights in work, be aj adapt to national circumstances and encourage local ownership. The inclusive and people-centered approach called for in the ILO Centenary Declaration for the Future of Work is needed now more than ever in order to protect workers' rights and rescue businesses and economies devastated by the strong socioeconomic and health impacts of the pandemic.

Taking into account the main challenges relating to rights at work, the Committee of Experts has identified at least three key challenges resulting from the pandemic

In the first place, although the exponential accumulation of executive powers in all countries is a natural consequence of the current circumstances and is aimed at safeguarding national security and public health and although the limitations of rights and freedoms respond to a great extent For a legitimate purpose, a number of parameters of international law still have to be met, in particular: i) the principle of legality, so that these restrictions are not arbitrary and are based on the law; ii) the principle of necessity, which requires the executive branch to prove that the limitations are truly necessary depending on the circumstances; iii) the principle of proportionality, which establishes the need to assess whether the restrictive measures are proportional to the risks and demands of the situation, and iv) the principle of non-discrimination against specific groups in society, while respecting the corresponding requirements contained in human rights treaties.

The second challenge consists of maintaining the universality, indivisibility, interdependence and interrelation of human rights, both civil and political rights, as well as economic, social and cultural rights. Human rights and international labor standards enshrine the universality and indivisibility of rights and freedoms. The ILO Declaration of Philadelphia calls for the guarantee of "conditions of freedom and dignity, of economic security and [of] equal opportunities", which would give effect to the ILO Constitution regarding what is known as interconnection. of civil and political rights and economic, social and cultural rights ${ }^{5}$

Third, the pandemic has exacerbated the plight of many groups that were already vulnerable to discrimination and marginalization. This is accentuated when there are several grounds of discrimination that are combined. As indicated at the beginning, many women, for example, are disadvantaged in accessing the labor market due to gender discrimination, and are further marginalized if they belong to disadvantaged groups. During the pandemic, it has become clear that the scourge of racial discrimination is on the rise and is extremely worrying. While COVID-19 does not discriminate, its effects and consequences may well.

${ }^{5}$ Declaración de Filadelfia, párr. II, a). 
On the basis of the information available ${ }^{6}$, the Commission observes that, from the early stages, it was appreciated that social protection is a crucial component of the response to the COVID-19 crisis and a means of mitigating its economic and social repercussions.. Unsurprisingly, countries with strong social protection systems, backed by a developed and robust health system, have been able to cope with the consequences of the COVID-19 pandemic and rapidly increase support for their affected populations. and efficiency. The response has been less effective in countries with fragmented social protection systems, mostly developing countries. They have not shown the same level of preparedness to face the crisis, given the lack of universal health coverage, unemployment insurance and sickness benefits for their population, which works mainly in the informal economy.

The effects of the pandemic are expected to worsen in the immediate future, and to be felt for a time. This may justify expanding or adjusting the scope of protection and the validity of current measures or taking additional measures, as appropriate, to strengthen social protection for all those who need it, in particular the most vulnerable, and allow societies better cope with the repercussions of the crisis. Aware of the costs associated with these measures, which will be necessary during a season, and of the challenge that Member States represent to ensure adequate financing during that time, the Commission recalls the principles of progressiveness, social solidarity, solidarity in terms of financing and economic, financial and fiscal sustainability, enshrined in the ILO social security standards.

Decent work demands in practice: agree on sufficient labor and social protection (social security, collective bargaining, salary social, among other measures considered as basic labor rights). Then, it must take care of rescuing the worker's participation within the company, in the telesis of a community of people, eradicating the mercantilist vision of labor relations, towards a model with a human face (Levinas)

Following Amartya Sen ${ }^{7}$, "invoking the idea of rights in the decent work document is neither in tension with the broad ethical framework based on objectives, nor has it been excluded by the need for perfect obligations, supposedly necessary for the idea of rights make sense ". But we cannot talk about decent work, if we do not first stop at society, there will be no decent work but only in a society that is decent. The framework that is established is based on the idea that there are some fundamental rights that must be recognized even if they are not proclaimed in the legislation because they are inherent to every decent society.

\footnotetext{
${ }^{6}$ La información proporcionada por los gobiernos en sus memorias sobre la aplicación de los convenios de la OIT y el Código Europeo de Seguridad Social, y la información recopilada por la OIT en una serie de publicaciones disponibles en las páginas web especializadas: La respuesta de la protección social a la crisis de la COVID-19 y State practice to address COVID-19 infection as a work-related injury (Prácticas de los Estados para abordar la infección por la COVID-19 como un accidente relacionado con el trabajo).

${ }^{7}$ Amartya Sen. Desarrollo y Libertad.- Barcelona: Planeta.2000.p. 231.
} 
Every so often, some statistics warn us about what was being processed right under our noses.

The deprivation of rights in the face of an identity without horizon seems to be the alarm that attends so many of us who see with amazement the harsh reality of the days.

The Social State of Law will not be possible if the bases of the social contract, of the moral contract that society demands, are not definitively rebuilt.

But it is necessary to rebuild ethics, an ethic of the future, but not an ethic of the future, but an ethic of the present that serves the future, and can lay the foundations for decent work, so that once and for all we can look forward to a real window without thinking that we are facing the illusory of some utopia.

I use to say with total sarcasm that Nietzche (Niche) must have lived in Argentina. The father of nihilism built "the myth of the eternal return", a philosophical theory that presents history as cycles that repeat themselves and that always end at the starting point and repeat themselves again.

Let's not make the miracle of living, which is pure evolution, an unchangeable textbook. As Borges wrote: "the spots on the skin are a map of the incorruptible constellations" ${ }^{\prime 8}$.

${ }^{8}$ Jorge Luis Borges. Ficciones. 2010, p. 165 